\title{
SEA LEVEL CHANGES ALONG THE COASTS OF KEA ISLAND AND PALEOGEOGRAPHICAL COASTAL RECONSTRUCTION OF ARCHAEOLOGICAL SITES
}

\author{
Mourtzas N.D. ${ }^{1}$ \\ ${ }^{1}$ Geologist PhD, Gaiaergon Geotechnical Firm., Kefallinias 16-18, 15231 Athens, Greece, \\ gaiaergon@gmail.com
}

\begin{abstract}
Sea level changes during the Upper Holocene submerged the coasts of Kea in three different phases about $5.50 \mathrm{~m}, 3.90 \mathrm{~m}$ and $1.50 \mathrm{~m}$ respectively below the contemporary sea level thus causing sea transgression along the shores of Kea, which varied from $8 \mathrm{~m}$ to $78 \mathrm{~m}$ depending on the coastal morphology.

These changes caused the alteration of the earlier morphology at coastal archaeological sites of the Island, as the prehistoric settlement of Ayia Irini and Classical period port of Karthaia, as well as, submerged under the sea areas of coastal human activity during antiquity, as the ancient schist quarry at Spathi bay.

The study of historical, geomorphological and sedimentological data indicative of previous sea levels allow the paleogeographical reconstruction of the coasts during the period of human activities in these areas.
\end{abstract}

Key words: sea level change, Kea Island, paleogeographic reconstruction, ancient ports, submerged ancient settlements, ancient quarries.

\section{Introduction: geomorphological features and geological structure of Kea Island}

The island of Kea, located at the western side of the Northern Cyclades island complex, has an area of $121 \mathrm{~km}^{2}$ and shores of total length of 86km (Fig. 1). The island's morphology is characterized by its intense topographic relief, which has an average gradient of $28 \%$, while its complex drainage system seems to be the upper part of an older one, broader and today nonexistent; whose greater part now lies under the sea surface. The types of landforms encountered at the coastal zone are Rias with craggy shores which maintain the character of a previous cycle of ground erosion.

The geological formations of the island are part of the "Northern Cyclades" geotectonic unit (Papanikolaou 1986) and include triassic - jurassic limestone and a metamorphic complex of marble, gneiss and schist (Davi 1976).

The triassic - jurassic limestone, located at the northern edge of the island (Fig. 1), have a maximum of thickness $100-150 \mathrm{~m}$ and they are found up-thrusted, possibly during Cretaceous, on top of the eroded surface of the metamorphic substratum.

Marbles with gneiss-schist intercalations comprises the upper members of the metamorphic system. 


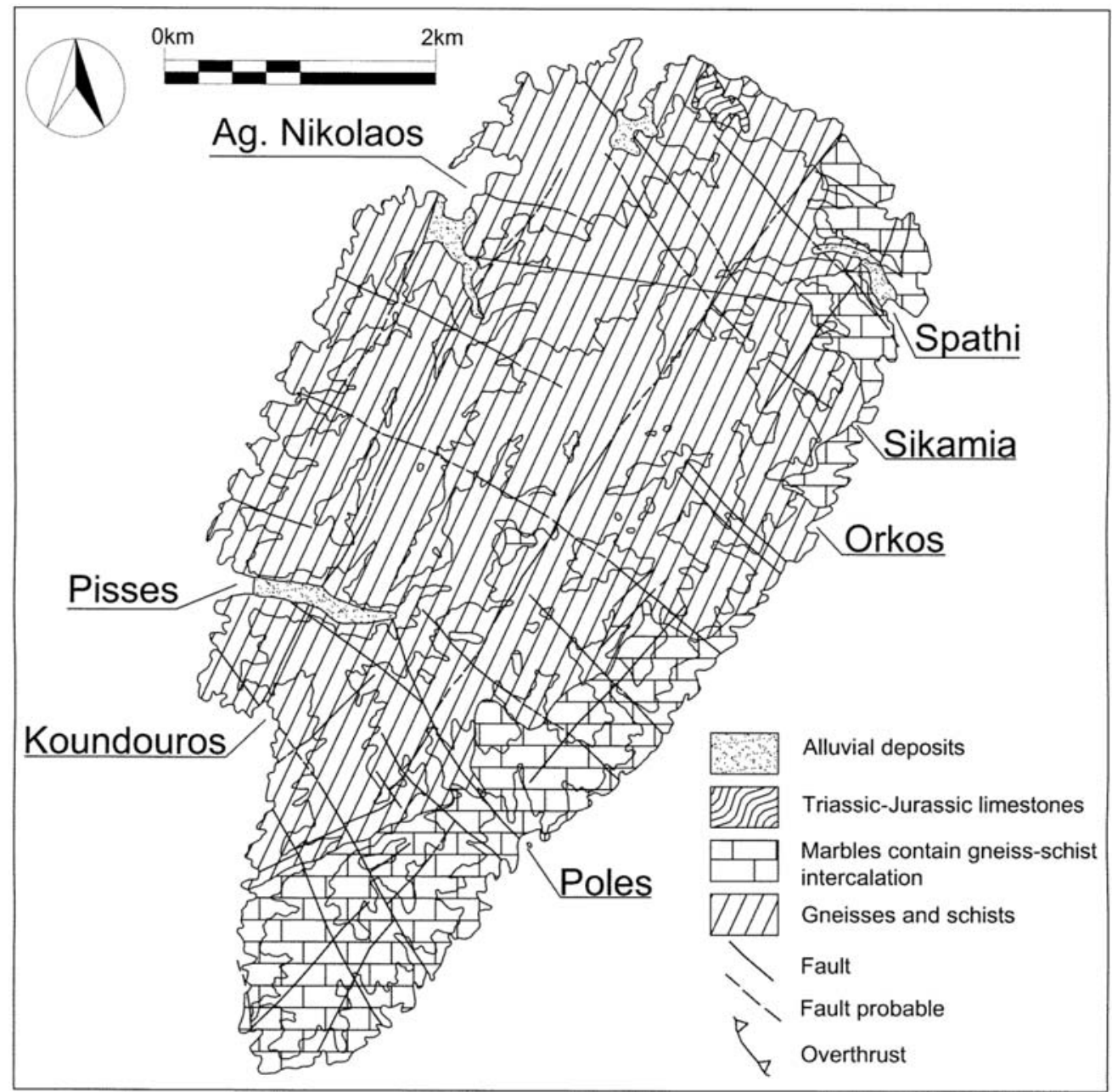

Fig. 1: Simplified geological map of Kea (Davi 1982) showing the position of the areas discussed.

In their contact on the transitional zone of the underlying gneisses and schists as also with the gneiss -schist intercalations, they change into cipolins, often accompanied by calc-schists.

The lower part of the metamorphic system, with a visible thickness more than $1000 \mathrm{~m}$, mainly consists of gneisses which often change into schists, therefore an irregularity occurs in their distribution.

The metamorphic complex is found intensely folded by two distinct folding phases, with NE-SW axial direction for the older phase and WNW-ESE for the younger. The main fault lines that cross the island and in some cases shape the morphology of its shores are of NE-SW and NW-SE directions. The NE-SW directed faults were created during a younger phase thus causing the shifting of the NW-SE directed faults of the older phase (Fig. 1). 
Table 1.

\begin{tabular}{|l|c|c|c|c|c|c|c|c|c|}
\hline \multicolumn{1}{|c|}{ Beach-rocks characteristics of Kea island } \\
\hline \multirow{3}{*}{ Site } & \multicolumn{2}{|c|}{$\begin{array}{c}\text { Width of beach-rock } \\
\text { formations }\end{array}$} & \multicolumn{2}{c|}{$\begin{array}{c}\text { Depth of the base of beach- } \\
\text { rock formations }\end{array}$} & \multicolumn{2}{c|}{$\begin{array}{c}\text { Depth of the top of beach- } \\
\text { rock formations }\end{array}$} \\
\cline { 2 - 14 } & $\begin{array}{c}\text { younger } \\
\text { phase } \\
(\mathrm{m})\end{array}$ & $\begin{array}{c}\text { middle } \\
\text { phase } \\
(\mathrm{m})\end{array}$ & $\begin{array}{c}\text { older } \\
\text { phase } \\
(\mathrm{m})\end{array}$ & $\begin{array}{c}\text { younger } \\
\text { phase } \\
(\mathrm{m})\end{array}$ & $\begin{array}{c}\text { middle } \\
\text { phase } \\
(\mathrm{m})\end{array}$ & $\begin{array}{c}\text { older } \\
\text { phase } \\
(\mathrm{m})\end{array}$ & $\begin{array}{c}\text { younger } \\
\text { phase } \\
(\mathrm{m})\end{array}$ & $\begin{array}{c}\text { middle } \\
\text { phase } \\
(\mathrm{m})\end{array}$ & $\begin{array}{c}\text { older } \\
\text { phase } \\
(\mathrm{m})\end{array}$ \\
\hline Spathi & 15.00 & - & - & -1.65 & - & - & -1.45 & - & - \\
\hline Sykamia & 15.00 & - & - & - & - & - & -1.95 & - & - \\
\hline Orkos & 10.00 & 43.00 & - & -2.05 & -3.20 & - & -1.90 & -2.45 & - \\
\hline Poles & 28.20 & 36.80 & 55.00 & -3.10 & -3.80 & -5.50 & -1.85 & -3.40 & -4.90 \\
\hline Koundouros & 7.50 & - & 78.00 & -0.70 & - & -4.60 & -1.50 & - & -4.10 \\
\hline Koundouros & 13.00 & 17.00 & - & -1.35 & -3.90 & - & -1.90 & -2.10 & - \\
\hline Koundouros & 10.00 & - & - & -0.80 & - & - & -1.20 & - & - \\
\hline Koundouros & 8.00 & - & - & - & - & - & -1.10 & - & - \\
\hline
\end{tabular}

\section{Indications of Upper Holocene sea-level changes}

Indications of sea-level changes along the shores of Kea are the submerged beach-rock formations, as well as the submerged ancient coastal constructions and settlements of the island. Coastal beachrock formations are found at the west shores of the island, at Koundouros location, submerged presently under the sea surface (Fig. 1 and table 1). In particular, measurements which were made at four small bays extending south of Koundouros bight revealed that the beach-rocks were deposited during three distinct phases, which all are now found completely submerged under the sea level.

The base and the top of the older phase, which is found at distance $78 \mathrm{~m}$ from present-day shore, are at depths of $-4.10 \mathrm{~m}$ and -4.60 , respectively. The middle phase, which is found at distance $17 \mathrm{~m}$ from present-day shore, has top and base depths of $-2.10 \mathrm{~m}$ and $-3.90 \mathrm{~m}$ and the younger phase, found at distances ranging from $7.50 \mathrm{~m}$ to $13 \mathrm{~m}$ from the shore, have its base and top depths ranging from $0.70 \mathrm{~m}$ to $-1.35 \mathrm{~m}$ and from -1.10 to $-1.90 \mathrm{~m}$, respectively.

On the east shores of Kea at Sykamia bay, beach-rock formations, stretching at the entire shoreline, have a width of $15 \mathrm{~m}$ and reach at a depth of $-1.95 \mathrm{~m}$. Southerly, at the Orkos bay, the beach-rocks occupy the entire coast and they are developed at two distinct phases. The middle phase, today completely submerged, has a width of $19.50 \mathrm{~m}$ while the depths of its base and top are $-3.20 \mathrm{~m}$ and $-2.45 \mathrm{~m}$, respectively, at a distance of $43 \mathrm{~m}$ from the shoreline. The younger phase of the beach-rocks at Orkos bay has a width of $10 \mathrm{~m}$ and the depths of its base and top are at $-2.05 \mathrm{~m}$ and -1.90 , respectively.

At the SE part of the island, at Poles Gulf, beach-rocks extending along the coasts of the two smaller bays of "Mikres Poles" and "Megales Poles" seem to have been formed during three distinct phases. The older phase was created by cemented deltaic deposits and at a distance of $55 \mathrm{~m}$ from shoreline the depths of its base and top are at $-5.50 \mathrm{~m}$ and at -4.90 , respectively. The middle phase of the beachrocks, at distances ranging from $13.75 \mathrm{~m}$ to $36.80 \mathrm{~m}$ from the shoreline, have the depth of its top from -2.40 to $-3.40 \mathrm{~m}$ and the depth of its base from $-2.20 \mathrm{~m}$ to $-3.80 \mathrm{~m}$. Finally, the younger phase of the 


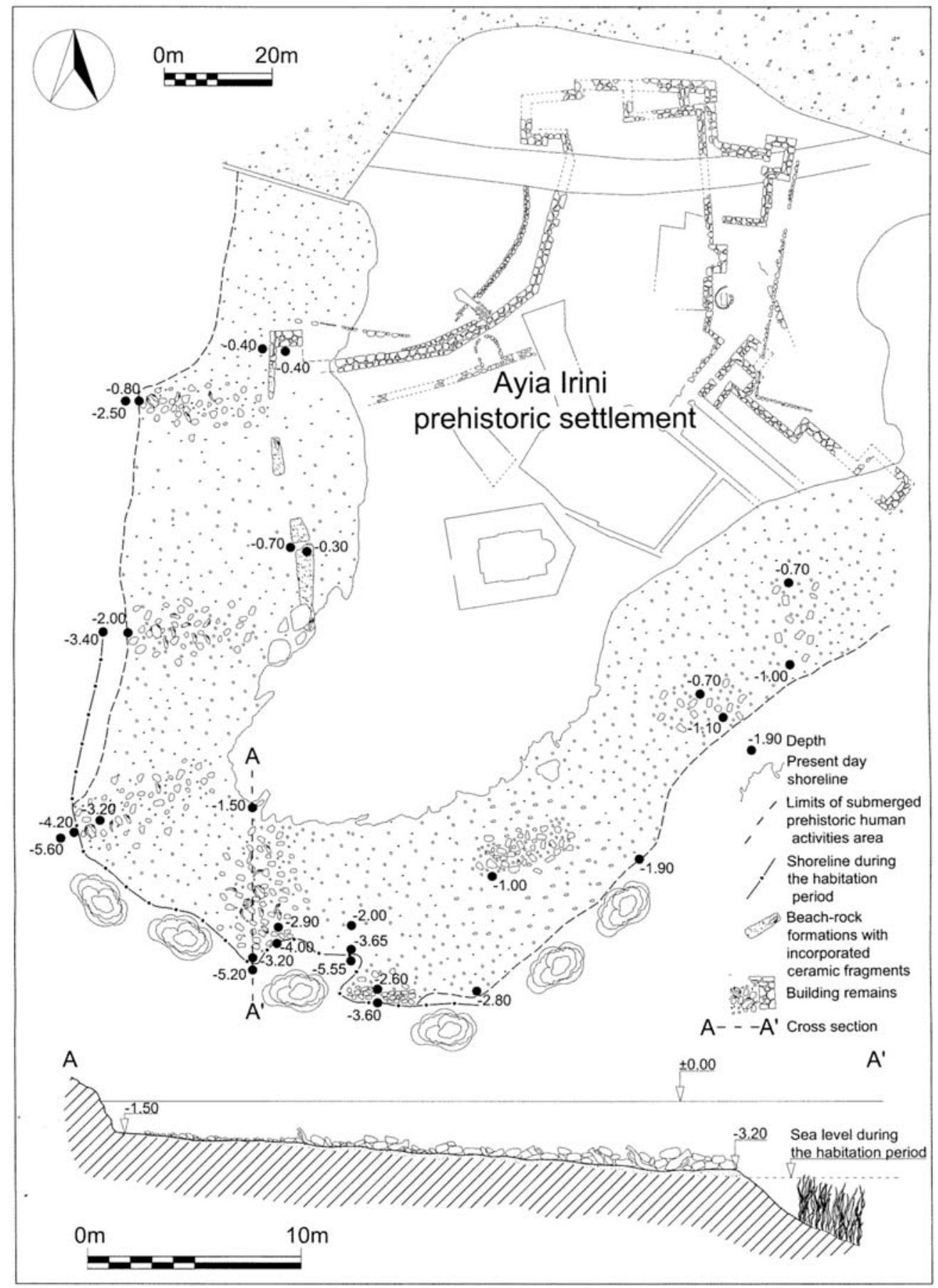

Fig. 2: Paleogeographic reconstruction of the coast of the prehistoric settlement of Ayia Irini. 
beach-rocks has its width ranging from $8.50 \mathrm{~m}$ to $28.20 \mathrm{~m}$ and the depths of its top are from $-0.80 \mathrm{~m}$ to $-1.85 \mathrm{~m}$ and its base are from $-1.35 \mathrm{~m}$ to $-3.10 \mathrm{~m}$.

\section{Paleogeographic changes of the shores during Upper Holocene}

Sea transgression along the shores of Kea, which varied from $15 \mathrm{~m}$ to $90 \mathrm{~m}$ depending on the coastal morphology, as a result of changes in sea-level, altered often radically the coastal paleogeomorphology. These changes abolished or degraded the coastal constructions and coastal human activities as well as parts of houses submerged under the sea surface.

\subsection{The prehistoric settlement of Ayia Irini}

The prehistoric settlement of Ayia Irini is located at the NE part of the shore of Ayios Nikolaos bay. This bay, located at NW shores of the island, is the only natural protected area for the mooring of ships at the north of the island. The natural setting in combination with its geographical location contributed in its development as a naval, commercial and strategic center from Neolithic Age to Classical period (Caskey 1962; Caskey 1964; Caskey 1966; Caskey 1971; Caskey 1972).

This Neolithic settlement was built on a small promontory. The habitation of the area, based on archaeological indications, started during the Neolithic Age. Archaeological research concludes the abrupt ending of the settlement operations and its possible abandonment in the period between the late Neolithic Age and Classical period, while a second period of abandonment took place at late Bronze Age, probably after an earthquake event.

Underwater research around the Ayia Irini promontory revealed that a great part of the settlement is today under the sea-level. The usage area, where the human activities occurred during antiquity, as it is defined by the ancient building ruins, the fragments of terracotta, ancient artifacts etc, surrounds the small promontory. The submerged part of the ancient settlement at the west side of the promontory has a length ranging from $35 \mathrm{~m}$ to $41 \mathrm{~m}$, at the south side from $25 \mathrm{~m}$ to $32 \mathrm{~m}$, while at the southwest side from $27.50 \mathrm{~m}$ to $33.50 \mathrm{~m}$ (Fig. 2). In this area, there were found building foundations, walls collapsed on pottery, abundance of terracotta fragments, as well as an accumulation of building stones at the south ending of the submerged part of the settlement, which indicates the construction of a quay wall for the protection of the settlement from sea erosion.

At the characteristic cross-section of the submerged part of the south side of the settlement (Fig. 2) the abrupt morphology as well as the growth of sea vegetation around the usage area is obvious. Based on the above characteristics we conclude at a sea-level lower some $3.40 \mathrm{~m}$ to $3.60 \mathrm{~m}$ from today sea-level, during the period that the settlement was active.

This rise of the sea-level is also confirmed by archaeological evidence from the excavations in the east part of Ayia Irini promontory, concerning the so-called "spring room" (Schofield 1998). The room's floor today lies $3.80 \mathrm{~m}$ lower than present sea-level. According to archaeological data this area was abandoned between $1450 \mathrm{BC}$ and $1375 \mathrm{BC}$ due to the salinity of the spring's water.

Finally, the absence of human activities after the Classical period probably is related to the rise of the sea-level and the consequent submergence of a large part of the settlement.

\subsection{The submerged schist quarry at Spathi bay}

At the south sheer rocky coast of Spathi bay, at a distance of $200 \mathrm{~m}$ from the sandy beach of the bay, a schist quarry was found. This is the only known quarry of that material in the whole area of the 
Cyclades. The traces of quarrying are preserved unaffected, at the terrestrial part of the quarry as well as at the submerged one, which is the larger of the two parts of this ancient quarry site. The quarrying method used doesn't have any particularity and follows the known method used during the antiquity in the Mediterranean basin.

The part of the quarry which lies above the sea-level has a length of $25 \mathrm{~m}$ and a width of $9.50 \mathrm{~m}$, while the submerged part of the ancient exploitation has a length of $25 \mathrm{~m}$ and the traces of quarrying reach a width of $10 \mathrm{~m}$ (Fig. 3).

At the front of the submerged part of the quarry, traces of the ancient quarrying activity are preserved, like burnings, grooves, channels, cuts for placing wedges and traces of quarrying equipment. At the bottom of the quarry between depths of $-2.50 \mathrm{~m}$ and $-5.00 \mathrm{~m}$, traces of detached blocks are found as well as large accumulations of quarrying debris. At the south limit of the quarry the abrupt slope of the bottom reaches a depth of $-9.50 \mathrm{~m}$ and it is covered by quarrying debris.

The layout of the quarrying area indicates a parallel to the sea-level changes evolution of the quarrying activity.

\subsection{Paleogeographic reconstruction of Poles Gulf}

The Poles golf, in a position sheltered by strong winds and sea waves at Kynthos strait, is delimited at its north and south sides by the craggy shore cliffs of Kafkasos and Pasalimani hill-chains, respectively.

In between, the rocky ramp of Aspri Vigla penetrates in the sea for some 25m, splitting the west sandy coast of the gulf into two smaller bays, "Mikres Poles" (also known as "Ayios Aimilianos") to the South and "Megales Poles" (also known as "Frea") to the North. In the middle of the gulf, aligned with the extension of Aspri Vigla and at a distance of $210 \mathrm{~m}$ from the shore, a small elongated islet of about $90 \mathrm{~m}$ length and $40 \mathrm{~m}$ width is located.

To the west, the hill-chain of "Aspri Vigla" is enclosed by "Eggeriti" and "Kato Meria" mountains; while at north and south it is delimited by two narrow elongated valleys crossed by "Kalamitsis" and "Vathypotamos" torrents whose riverbeds lead to the bays of "Megales" and "Mikres Poles", respectively. Sea-level change indications at Poles gulf are as follow:

- The few historical references on the existence of port installations during antiquity (Thomopoulos 1963; Osborne 1988).

- The engraved inscription on the northern craggy cliff shore of "Megales Poles bay", at a height about $1.00 \mathrm{~m}$ above the sea-level and a distance of $25 \mathrm{~m}$ from the sandy beach, today accessible only by the sea, which is dated -based on the type of its letters- at the 3rd century BC (Manthos 1867; Physllas 1921).

- The submersion of the connecting trail between the two bays in front of the "Aspri Vigla" promontory.

- The various carvings on the rocky islet as well as a circular reception of $0.22 \mathrm{~m}$ diameter and $0.03 \mathrm{~m}$ depth, found at its northeast side, which could have been used as a supporting base of a small pillar, all presently covered by the sea, even by a slightly intense sea undulation (Manthos 1867).

On the sheer south side of the small projection formed by the eastern edge of "Aspri Vigla" as well as at various points along the craggy $\mathrm{N}$ and $\mathrm{S}$ rocky coast of the gulf, submerged sea-notches at depths between $-1.0 \mathrm{~m}$ to $-1.10 \mathrm{~m}$ are found. This older sea-notch is recognizable from the horizon- 


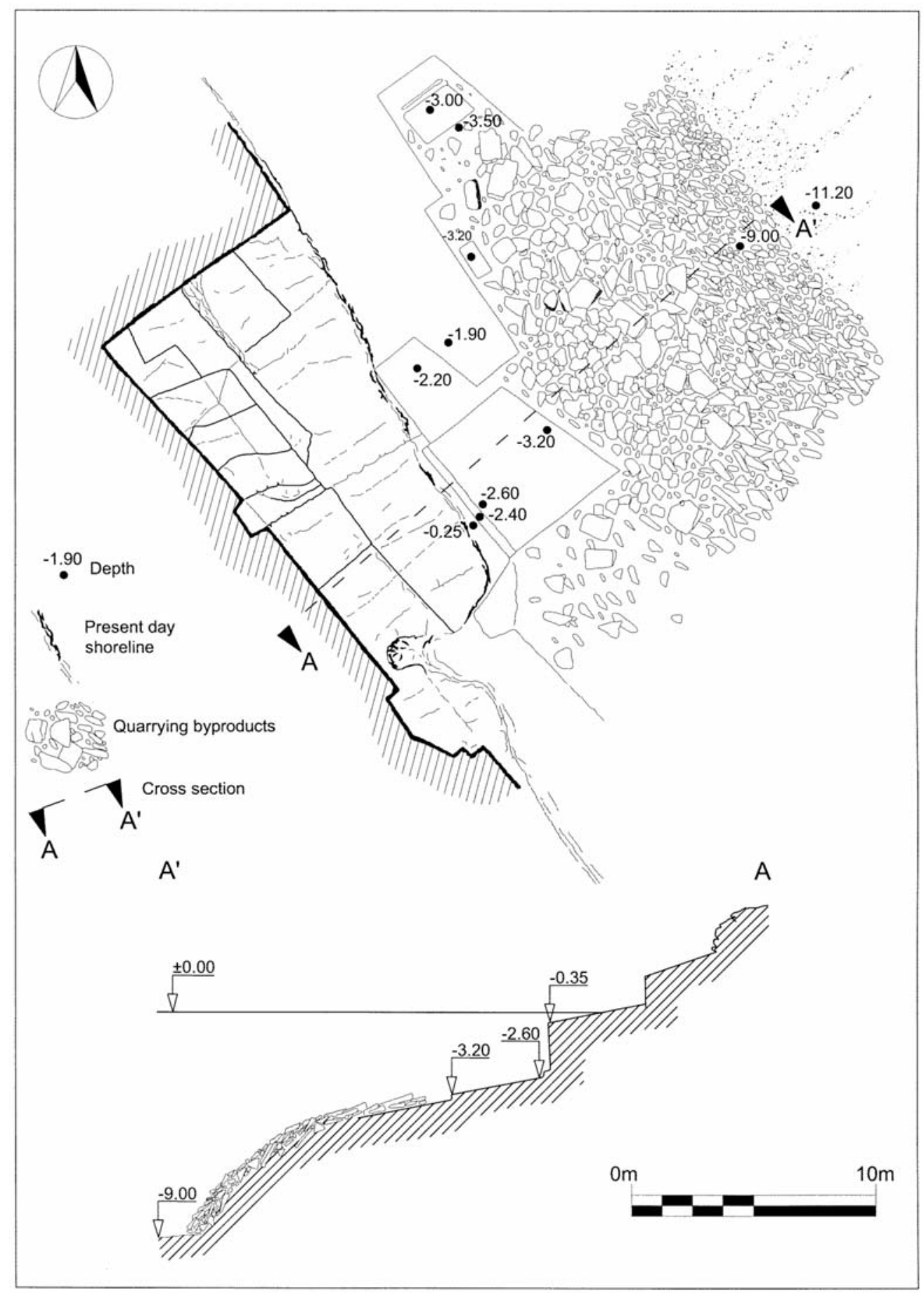

Fig. 3: Plan and charachteristic cross section of the submerged schist quarry at Spathi rocky coast. 
Table 2.

\begin{tabular}{|c|c|c|c|c|c|c|c|c|c|}
\hline \multicolumn{10}{|c|}{ Beach-rocks characteristics of the Poles gulf } \\
\hline \multirow[b]{2}{*}{ Site } & \multicolumn{3}{|c|}{$\begin{array}{l}\text { Width of beach-rock } \\
\text { formations }\end{array}$} & \multicolumn{3}{|c|}{$\begin{array}{c}\text { Depth of the base of beach-rock } \\
\text { formations }\end{array}$} & \multicolumn{3}{|c|}{$\begin{array}{c}\text { Depth of the top of beach- } \\
\text { rock formations }\end{array}$} \\
\hline & $\begin{array}{c}\text { younger } \\
\text { phase } \\
(\mathrm{m})\end{array}$ & $\begin{array}{c}\text { middle } \\
\text { phase } \\
(\mathrm{m})\end{array}$ & $\begin{array}{c}\text { older } \\
\text { phase } \\
(\mathrm{m})\end{array}$ & $\begin{array}{l}\text { younger } \\
\text { phase } \\
(\mathrm{m})\end{array}$ & $\begin{array}{c}\text { middle } \\
\text { phase } \\
(\mathrm{m})\end{array}$ & $\begin{array}{l}\text { older } \\
\text { phase } \\
(\mathrm{m})\end{array}$ & $\begin{array}{c}\text { younger } \\
\text { phase } \\
\text { (m) }\end{array}$ & $\begin{array}{c}\text { middle } \\
\text { phase } \\
(\mathrm{m})\end{array}$ & $\begin{array}{c}\text { older } \\
\text { phase } \\
(\mathrm{m})\end{array}$ \\
\hline $\mathrm{A}$ & 8.55 & 21.20 & & -1.35 & -3.00 & & -0.90 & -2.40 & \\
\hline $\mathrm{B}$ & - & 22.80 & & - & -2.50 & & - & -2.20 & \\
\hline $\mathrm{C}$ & 10.60 & - & & -1.60 & - & & -0.80 & - & \\
\hline $\mathrm{D}$ & - & 18.20 & & -2.00 & - & & -1.60 & - & \\
\hline $\mathrm{E}$ & 14.30 & 41.00 & & -1.75 & -4.30 & & -1.20 & -2.40 & \\
\hline $\mathrm{F}$ & - & 13.75 & & - & -4.16 & & - & -2.86 & \\
\hline $\mathrm{G}$ & - & 26.80 & & - & -4.10 & & - & -2.90 & \\
\hline $\mathrm{K}$ & - & 35.00 & & - & -4.15 & & - & -3.40 & \\
\hline $\mathrm{L}$ & 26.80 & 31.00 & & -2.00 & -3.30 & & -1.20 & -2.75 & \\
\hline $\mathrm{M}$ & 28.20 & 34.00 & & -2.35 & -3.30 & & -1.20 & -2.60 & \\
\hline $\mathrm{N}$ & 23.00 & 36.80 & & -2.38 & -3.80 & & -1.00 & -3.05 & \\
\hline $\mathrm{O}$ & 22.00 & - & 55.00 & -3.10 & - & -5.50 & -1.85 & - & -4.90 \\
\hline
\end{tabular}

tal grooving, with an opening of $0.80 \mathrm{~m}$, in the marble layers. The groove is typical asymmetrical cut with a broad slightly inclined base and sheer rough top.

The submerged beach-rocks, which are found along the entire length of the southern (Mikres Poles) and northern (Megales Poles) portions of the bay's western shore, seems to have been formed during two different phases, each of which reflects a period of stability for the two different sea-levels (Fig. 4-left). The presence of sherds and tiles found in the beach-rocks of both two phases are clear indications that were formed after human settlement in the area.

Measurement results showed that the maximum width of the older and deeper phase of the rock formations reaches some $40 \mathrm{~m}$, while the maximum depth of the top of the rocks is $-3.40 \mathrm{~m}$. The most recent phase of the beach-rocks possess a maximum width of $28 \mathrm{~m}$, while the depth of their tops coincides with the depth of the ancient shoreline, varying between $-0.80 \mathrm{~m}$ and $-1.20 \mathrm{~m}$ (Table 2).

Measurements which were taken on the north side of "Aspri Vigla" promontory indicate that the beach-rocks in this location were formed during the middle phase, while the younger phase is not apparent due to the disappearance of the sandy shore along the entire length of the promontory, as a consequence of the rise in sea-level.

The parts of the beach-rocks which project from the southern extremities of "Mikres" and "Megales Poles" bays coincides with the points of outflow of the torrents of "Bathypotamos" and "Kalamitsi", which in turn indicates that the beack-rocks are actually the small fossilized deltas of these torrents. The appearance of beach-rocks at the northern extremity of "Megales Poles" bay seems to have been created by fossilized deposits of an older outflow point of "Kalamitsi" torrent. 


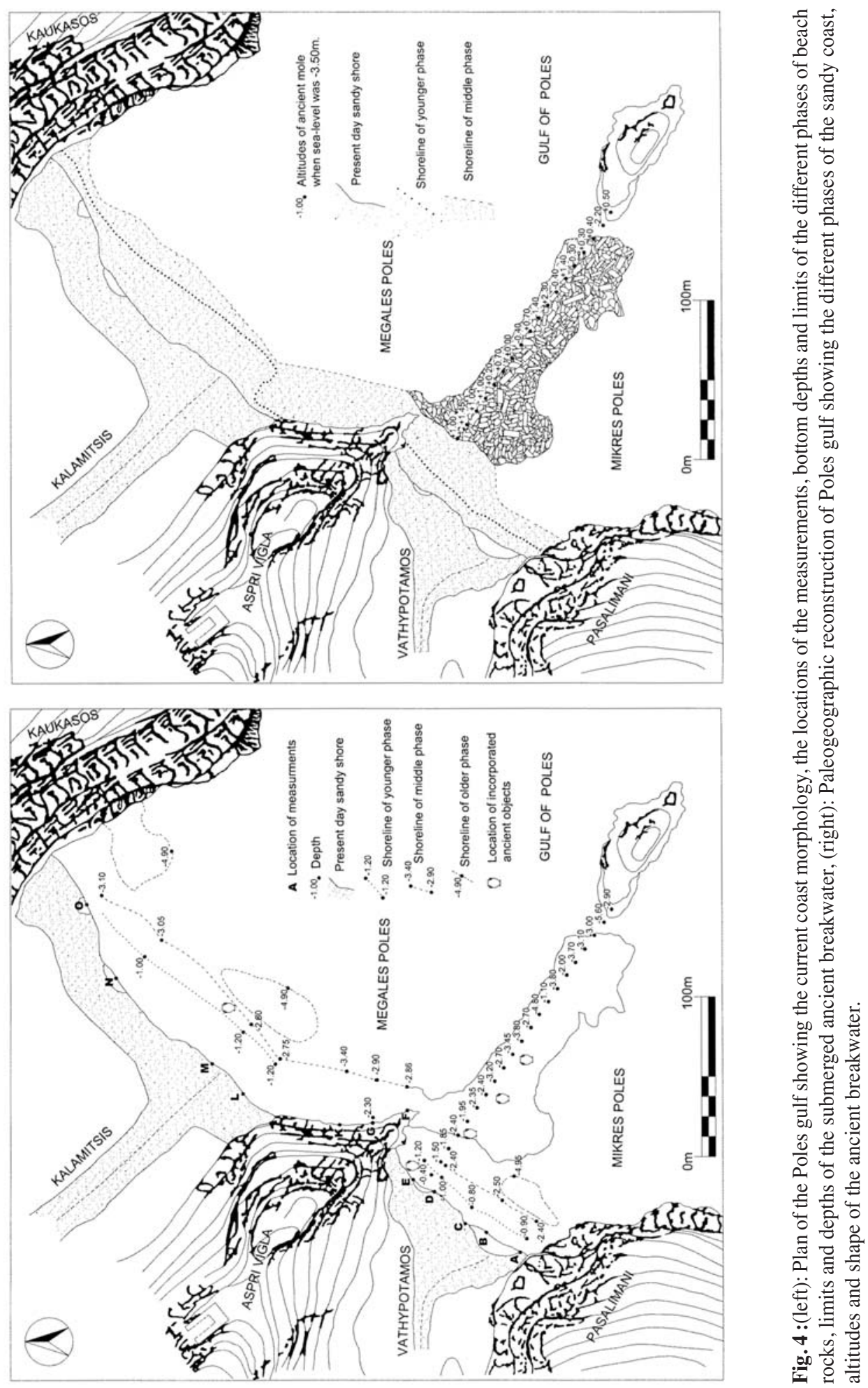


On the basis of the data obtained from the investigation of the ancient sea notches and the beachrocks it is concluded that the morphology of the western shore of the bay altered in two separate phases in accordance with the fluctuations of the sea-level in this region. The reconstruction of the coastal morphology during these two phases is attempted in figure 4-right.

During the period when the sea-level was some $-3.40 \mathrm{~m}$ lower than today, as low as the maximum depth of the tops of the older phase of the beach-rocks, the sandy western shore of the bay was wider than the contemporary and extended seawards for some $21 \mathrm{~m}$ to $40 \mathrm{~m}$. During the second and more recent phase when the sea-level was $1.20 \mathrm{~m}$ lower than present one, as low as the maximum depth of the tops of the second phase of the beach-rocks, and also the depth of the ancient sea notches, the western shore was some $8 \mathrm{~m}$ to $28 \mathrm{~m}$ east of its present location; while the narrow sandy beach which existed in the older phase in front of the promontory of "Aspri Vigla", no longer appears.

The small fossilized deltas of the torrents which run into the Poles gulf, the depth of the tops and the bases of which are $-4.90 \mathrm{~m}$ and $-5.50 \mathrm{~m}$, respectively, were probably formed during an earlier phase than that of the two previous phases, when the sea-level was $-4.90 \mathrm{~m}$ lower than today.

In the course of the underwater investigation of the area between the coast of "Mikres Poles" and the islet, an underwater mound of $160 \mathrm{~m}$ length and of $30 \mathrm{~m}$ to $35 \mathrm{~m}$ width was identified. This underwater mound lies some $40 \mathrm{~m}$ from the shore in a SE direction and terminates at the islet. The mound is composed of large schist boulders, agglomerated bits of schistolithic rock and schist slabs cemented together with sandy cement containing shell and terracotta fragments. The presence of sherds and tiles, as well as the base of a large bronze vessel struck to the surface of the mound, is evidence of human activity here in the past. Detailed measurements taken along the length of the mound revealed that when sea-level was at $-3.40 \mathrm{~m}$, the presently submerged mound protruded from the surface some $0.20 \mathrm{~m}$ to $2.30 \mathrm{~m}$ (Fig. 4-right).

This morphology constituted a manmade breakwater which further protected from wind and wave an already well-sheltered location and allowed the safe mooring of ships in the harbour. During the second phase, when sea level rose some $2.20 \mathrm{~m}$, the breakwater was completely submerged (Fig. 4right). A channel $8 \mathrm{~m}$ wide, presently submerged, situated between the eastern end of the breakwater and the islet, allowed for the passage of shipping from one side of the gulf to the other.

Approximately two and a half millennia ago the sea-level in this region was $3.40 \mathrm{~m}$ lower than today while the sandy beach was wider some $20 \mathrm{~m}$ to $40 \mathrm{~m}$ than today at various points. Land communication between the north and south shores of the gulf was possible via the narrow sandy beach which lay before the sheer rocky cliff of the promontory of "Aspri Vigla". Most likely the traces of the ancient path connecting "Mikres" with "Megales Poles" should be sought to the east of the modern animal track, which apparently was formed after the collapse of the east side of the terrace where the Temple of Apollo stood. This collapse brought down the corresponding wall of the temple which stood at the eastern edge of the town (Fig. 4-right). The presently submerged breakwater, stretching between the islet and the sandy coast, which was a rocky ridge partially filled with slabs of marble and schist, stood above the surface of the sea creating the harbour mole of the ancient Karthaia port.

\section{Conclusions}

Sea-level changes along the shores of Kea during Upper Holocene seem that they have occurred in three distinct phases.

The older phase is defined by a sea-level lower than the contemporary by $4.60 \mathrm{~m}$ to $5.50 \mathrm{~m}$. Indica- 
tions of this sea-level are the older beach-rock phase at Koundouros shores as well as the submerged fossilized deltas of the torrents at Poles gulf.

The following middle phase corresponds to a sea-level $3.40 \mathrm{~m}$ to $3.90 \mathrm{~m}$ lower than the contemporary. Indications of the middle phase are located at Koundouros shores at the east side of Kea and at Sykamia and Poles gulf at the west side, where beach-rock formations are submerged at related depths. At Ayios Nikolaos, Spathi and Poles gulfs, the middle sea-level is also established by the submerged part of Ayia Irini settlement, the submerged ancient quarry and the harbour installations of ancient Karthaia, respectively. Based on archaeological evidence, this phase of sea-level correlates to the Classical era about two and a half millennia from present day.

The younger phase corresponds to a sea-level $1.10 \mathrm{~m}$ to $1.50 \mathrm{~m}$ lower than the contemporary. Indications of the this phase are located at Koundouros shores, at Spathi, Sykamia, Orkos and Poles gulfs, where beach-rock formations and coastal installations are submerged at related depths.

In antiquity, coastal geomorphological features apparently were a major factor in the selection of a coastal location to establish a settlement. People tried to benefit from natural protected coastal morphology, in some cases improve it with small scale interventions, while in only few locations they resorted to extensive harbor projects for the safe access of the ships. Sea-level changes during Upper Holocene altered the paleogeography of the shore and overturned the comparative advantage of a coastal location thus contributing in its decline. Paleogeographic reconstruction of the prehistoric settlement of Ayia Irini and the Classical period port of Karthaia on the island of Kea offer important elements for understanding the selection criteria during antiquity and contribute to the interdisciplinary research.

\section{References}

Caskey, L.J., 1962. Excavations in Keos 1966-1970. Hesperia 31, 1962, pp. 263-283.

Caskey, L.J., 1964. Excavations in Keos 1966-1970. Hesperia 33, 1964, pp. 314-335.

Caskey, L.J., 1966. Excavations in Keos 1966-1970. Hesperia 35, 1966, pp. 363-376.

Caskey, L.J., 1971. Investigasions in Keos I. Hesperia 40, 1971, pp. 358-396.

Caskey, L.J., 1972. Investigasions in Keos II. Hesperia 40, 1972, pp. 357-401.

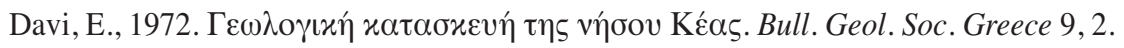

Davi, E., 1982. Geological map of Greece 1:50.000, Kea island, IGME 1982

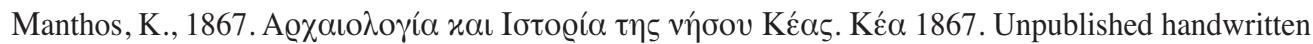
ms. In Archives of the BSA, Athens. N73.

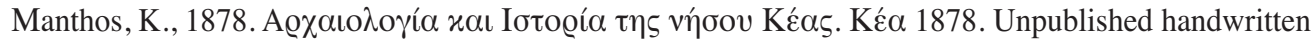
ms. In Archives of the Greek Historical and Ethnological Society, nr. 132.

Papanikolaou, D., 1986. The Geology of Greece. 240, Athens.

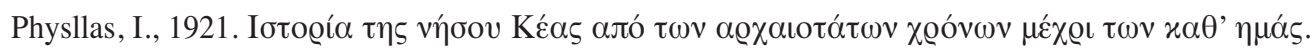
A $\theta$ íva 1921, 298.

Schofield, E., 1998. Town planning at Ayia Irini, Kea. Kea-Kythnos: History and Archaeology Proceeding of an International symposium Kea-Kythnos, 1994, 117-121.

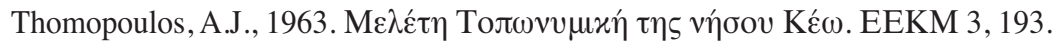

